\title{
Математична модель польоту елементу, що тралить натяжні датчики цілі вибухонебезпечних предметів
}

\author{
Володимир Кривцун * 1 А; Олексій Агеєв ${ }^{2}$ А; Олег Бондаренко 3 В \\ А Національна академія сухопутних військ імені гетьмана Петра Сагайдачного, Львів, Україна \\ в Інститут державного управління та наукових досліджень з цивільного захисту, Київ, Україна
}

Received: December 3, 2021 | Revised: December 15, 2021 | Accepted: December 30, 2021

DOI: $10.33445 /$ sds.2021.11.6.9

\begin{abstract}
Анотація
На основі аналізу існуючих підходів щодо моделювання процесів розмінування, зокрема використання засобів для тралення натяжних датчиків цілі вибухонебезпечних предметів, запропонована модель польоту елементу, що тралить натяжні датчики цілі, яка, на відміну від існуючих, враховує приріст питомої маси засобу для тралення (комбінація елементу, що тралить, і тросу) під час польоту. Одним із найбільш складних питань під час моделювання $\epsilon$ визначення залежності параметрів польоту елементу, що тралить, від динаміки приросту маси тросу (шнура). Балістичними параметрами елементу, що тралить, які досліджуються, є: кут вильоту, дальність, висота, час, швидкість польоту. Запропоновані удосконалення математичної моделі та послідовності проведення розрахунків дозволять підвищити точність результатів моделювання процесу тралення натяжних датчиків цілі вибухонебезпечних предметів під час обгрунтування вимог до засобів розмінування даного типу. Напрямами подальших досліджень $є$ математичне моделювання процесу польоту елементу, що тралить, які входять до складу засобів для тралення натяжних датчиків цілі вибухонебезпечних предметів, та обгрунтування, на основі використання його результатів, раціональних балістичних параметрів.
\end{abstract}

Ключові слова: модель польоту, вибухонебезпечний предмет, натяжний датчик цілі, тралення, елемент, що тралить.

\section{Постановка проблеми}

В результаті ведення бойових дій на сході нашої країни значна площа території місцевості виявилася замінованою як протитанковими так і протипіхотними вибухонебезпечними предметами. Більшість вибухонебезпечних предметів (ВНП), які використовуються, оснащені натяжними датчиками цілі. Незважаючи на заборону використання протипіхотних ВНП рядом міжнародних конвенцій гібридні війська країни-агресора Російської Федерації все частіше використовую заборонені ВНП 3 натяжними датчиками цілі, зокрема, протипіхотну міну пОМ-2, яка встановлюється в основному дистанційно [1].
Застосування ВНП з натяжними датчиками цілі збільшує їх ефективність в рази, в наслідок чого відбуваються підриви не лише особового складу ЗС України, але і цивільного населення. Проте, ВНП 3 натяжними датчиками цілі встановлюються не тільки в протипіхотних варіантах, але і в протитанкових та протитранспортних, що призводить до знищення ОВТ. Зрозуміло, що місця встановлення зазначених ВНП противником невідомі.

Статистика поранених та загиблих через спрацювання вибухонебезпечних предметів серед цивільного населення та військовослужбовців Збройних Сил України

\footnotetext{
1 * Corresponding author: к.тех.н., старший науковий співробітник, e-mail: vol.kryvtsun@gmail.com, ORCID: 0000-0002-3907-5320

2 ад'юнкт науково-організаційного відділу, e-mail: aheyev1979@ukr.net

3 кандидат військових наук, доцент, доцент кафедри, e-mail: dinamo_kiev7@ukr.net_ORCID: 0000-0001-5360-0120
} 
наведено на рисунку 1, втрати у бронетехніці на рисунку 2.
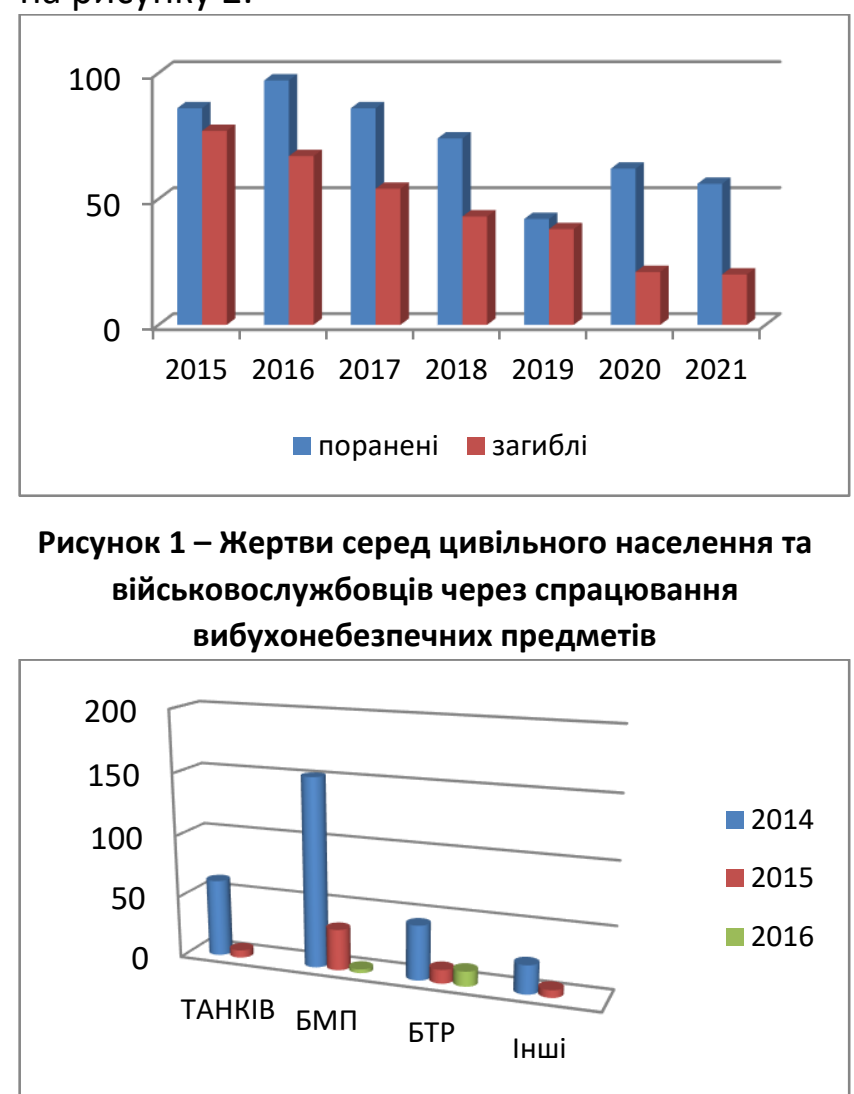

Рисунок 2 - Втрати зС України у бронетехніці від підриву на вибухонебезпечних предметах на протязі 2014-2016 років

Одним із найбільш ефективних способів знищення ВНП даного типу залишається їх тралення, яке на сьогоднішній день у Збройних Силах України здійснюється закиданням вручну на заміновану ділянку місцевості елементу, що тралить (ТE), із подальшим його підтягуванням за допомогою тросу [2].

Але такий варіант виконання завдання щодо розвідки та розмінування місцевості має низку серйозних недоліків, серед яких основними є: великий ризик для особового складу саперів через те, що невідомо на якій відстані розташовані безпосередньо ВНП, низька точність попадання TE, невелика дальність закидання, обмеження щодо використання таких засобів у забудованій та залісеній місцевості. Визначені недоліки можуть бути усунуті за рахунок впровадження в практику розмінування місцевості та об'єктів перспективних засобів тралення ВНП із натяжним датчиком цілі. За таких умов постає проблемне питання обгрунтування вимог до засобів розмінування даного типу із врахуванням балістичних параметрів процесу дистанційного тралення.

Актуальність останнього підтверджується вимогами керівних документів [2-5] та набутим досвідом. Вирішення визначеного проблемного питання стає можливим за рахунок моделювання із використанням удосконаленого науково-методичного апарату.

\section{Аналіз останніх досліджень та публікацій}

Питання дослідження процесу тралення ВНП із натяжним датчиком цілі приділялася недостатня увага. Так в $[2,6]$ розглядається лише порядок дій підрозділів на території, де можливе застосування саморобних вибухових пристроїв, в тому числі і 3 натяжними датчиками цілі. Оцінювання ефективності подовжених зарядів розмінування розглянуті в [7], згідно з чим ефективність зосереджених, подовжених та сітчастих зарядів розмінування оцінюється 3 боку впливу вибуху на міну. Крім того оцінюється вибухостійкість інженерних боєприпасів із натяжними датчиками цілі. Механічне тралення у роботах $[6,7]$ не розглядається. У $[8,9]$ розглянута задача визначення параметрів польоту тіла кинутого під кутом до горизонту, яка може бути покладена в основу балістичної моделі тралення ВНП з натяжним датчиком цілі. На відміну від тіла, яке розглядається у [8], в нашому випадку сума маси TE $m$ і питомої маси тросу $m_{\text {тр }}$ під час польоту буде змінюватись внаслідок витягування (зміни довжини l) останнього. Отже, для визначення балістичних параметрів засобу для тралення 
(3Т) під час їх використання підхід [9] потребує удосконалення.

\section{Постановка завдання}

Метою статті $\epsilon$ висвітлення основних положень розробленої моделі польоту елементу, що тралить натяжні датчики цілі вибухонебезпечних предметів в умовах змінної маси засобу тралення.

\section{Виклад основного матеріалу}

Одним із найбільш складних питань під час моделювання $\epsilon$ визначення залежності параметрів польоту TE від динаміки збільшення маси $m(x)$ ЗТ (комбінація ТЕ і тросу).
На початок умовно представимо ТЕ як тіло постійної маси кинуте під кутом.

Вихідні дані для проведення розрахунків за варіантами різних кутів кидання TE, представлені в таблиці 1.

Таблиця 1 - Вихідні данні для проведення розрахунків кидання елементу що тралить

\begin{tabular}{|c|c|c|c|c|c|c|c|c|}
\hline № & $F_{\text {пр, }}, \mathrm{H}$ & $m, \mathrm{кг}$ & $\alpha$, град. & $L_{c}, M$ & $t$, сек & $k_{0}$ & $F_{\mathrm{T}}, \mathrm{H}$ & $F, \mathrm{H}$ \\
\hline 1 & 50 & 0,1 & 0 & 0,5 & 0,7 & 0,6 & 0 & 50,0 \\
\hline 2 & 50 & 0,1 & 5 & 0,5 & 0,7 & 0,6 & 0,09 & 49,9 \\
\hline 3 & 50 & 0,1 & 10 & 0,5 & 0,7 & 0,6 & 0,17 & 49,8 \\
\hline 4 & 50 & 0,1 & 15 & 0,5 & 0,7 & 0,6 & 0,25 & 49,7 \\
\hline 5 & 50 & 0,1 & 20 & 0,5 & 0,7 & 0,6 & 0,34 & 49,7 \\
\hline 6 & 50 & 0,1 & 25 & 0,5 & 0,7 & 0,6 & 0,41 & 49,6 \\
\hline 7 & 50 & 0,1 & 30 & 0,5 & 0,7 & 0,6 & 0,49 & 49,5 \\
\hline 8 & 50 & 0,1 & 35 & 0,5 & 0,7 & 0,6 & 0,56 & 49,4 \\
\hline 9 & 50 & 0,1 & 40 & 0,5 & 0,7 & 0,6 & 0,63 & 49,4 \\
\hline 10 & 50 & 0,1 & 45 & 0,5 & 0,7 & 0,6 & 0,69 & 49,3 \\
\hline 11 & 50 & 0,1 & 50 & 0,5 & 0,7 & 0,6 & 0,75 & 49,2 \\
\hline 12 & 50 & 0,1 & 55 & 0,5 & 0,7 & 0,6 & 0,80 & 49,2 \\
\hline 13 & 50 & 0,1 & 60 & 0,5 & 0,7 & 0,6 & 0,85 & 49,2 \\
\hline 14 & 50 & 0,1 & 65 & 0,5 & 0,7 & 0,6 & 0,89 & 49,1 \\
\hline 15 & 50 & 0,1 & 70 & 0,5 & 0,7 & 0,6 & 0,92 & 49,1 \\
\hline 16 & 50 & 0,1 & 75 & 0,5 & 0,7 & 0,6 & 0,95 & 49,1 \\
\hline 17 & 50 & 0,1 & 80 & 0,5 & 0,7 & 0,6 & 0,96 & 49,0 \\
\hline 18 & 50 & 0,1 & 85 & 0,5 & 0,7 & 0,6 & 0,98 & 49,0 \\
\hline 19 & 50 & 0,1 & 90 & 0,5 & 0,7 & 0,6 & 0,98 & 49,0 \\
\hline
\end{tabular}

Розрахункова схема метання такого тіла представлена на рис. 1.

До балістичних параметрів польоту ТЕ згідно аналізу проведених розрахунків відносяться: кут вильоту $\theta_{0}$, максимальна дальність $L$ (рис. 2), висота $H$ (рис.3), час $T$ (рис. 4), початкова швидкість $V_{0}$ (рис. 5), швидкість $V_{x}$ польоту ТЕ.
TE, отримавши початкову швидкість $V_{0}$, рухається у середовищі, що чинить опір, по деякій траєкторії до тих пір, доки не впаде на землю. Для дослідження параметрів визначеної траєкторії побудуємо рівняння польоту TE, які кинуті під кутом $\theta_{0}$ з початковою швидкістю $V_{0}$, на основі схеми (рис. 1, 5). 


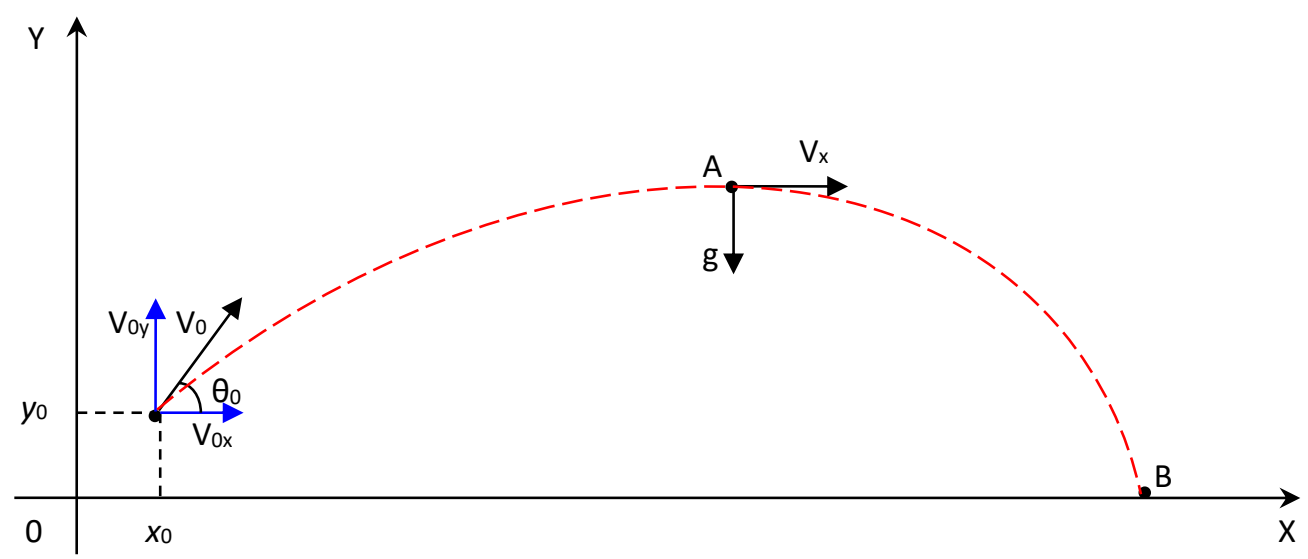

Рисунок 1 - Побудова траєкторії польоту тіла, кинутого під кутом [13]

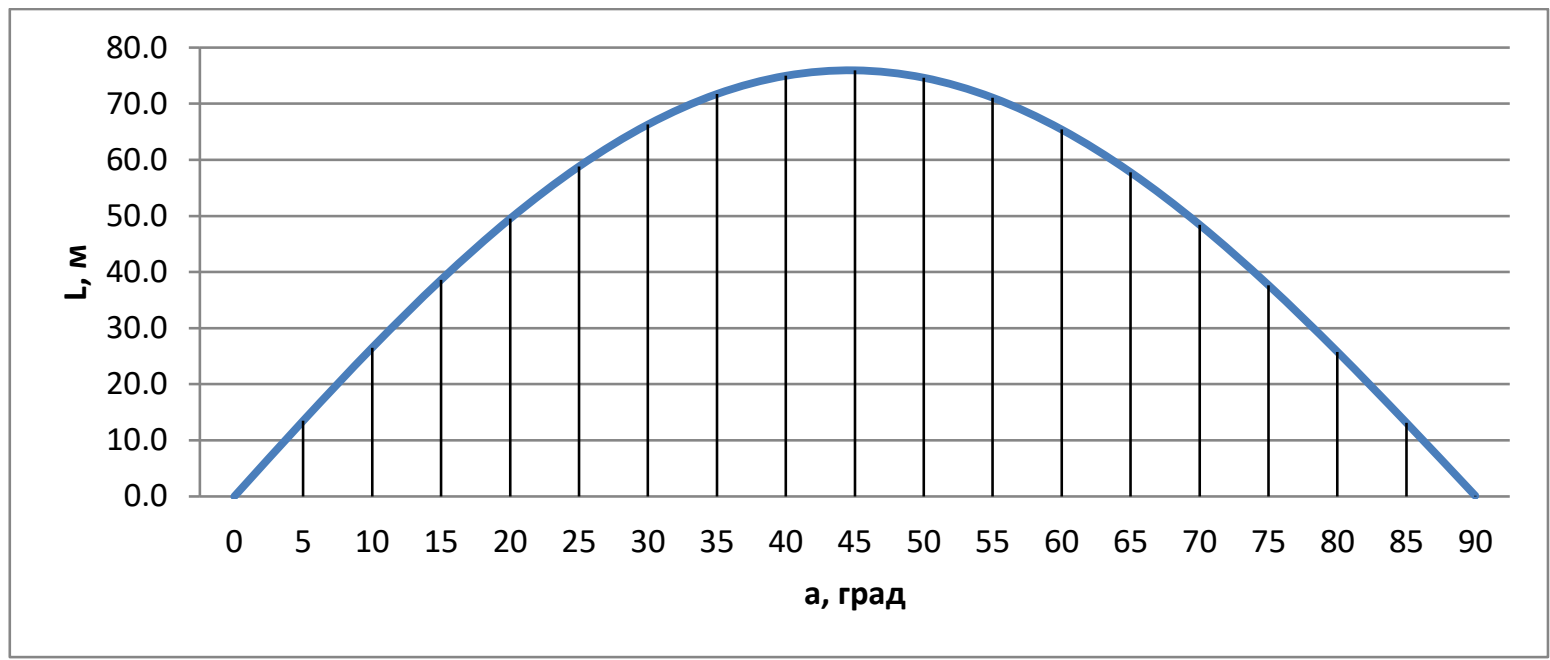

Рисунок 2 - Очікуване віддалення польоту елементу що тралить

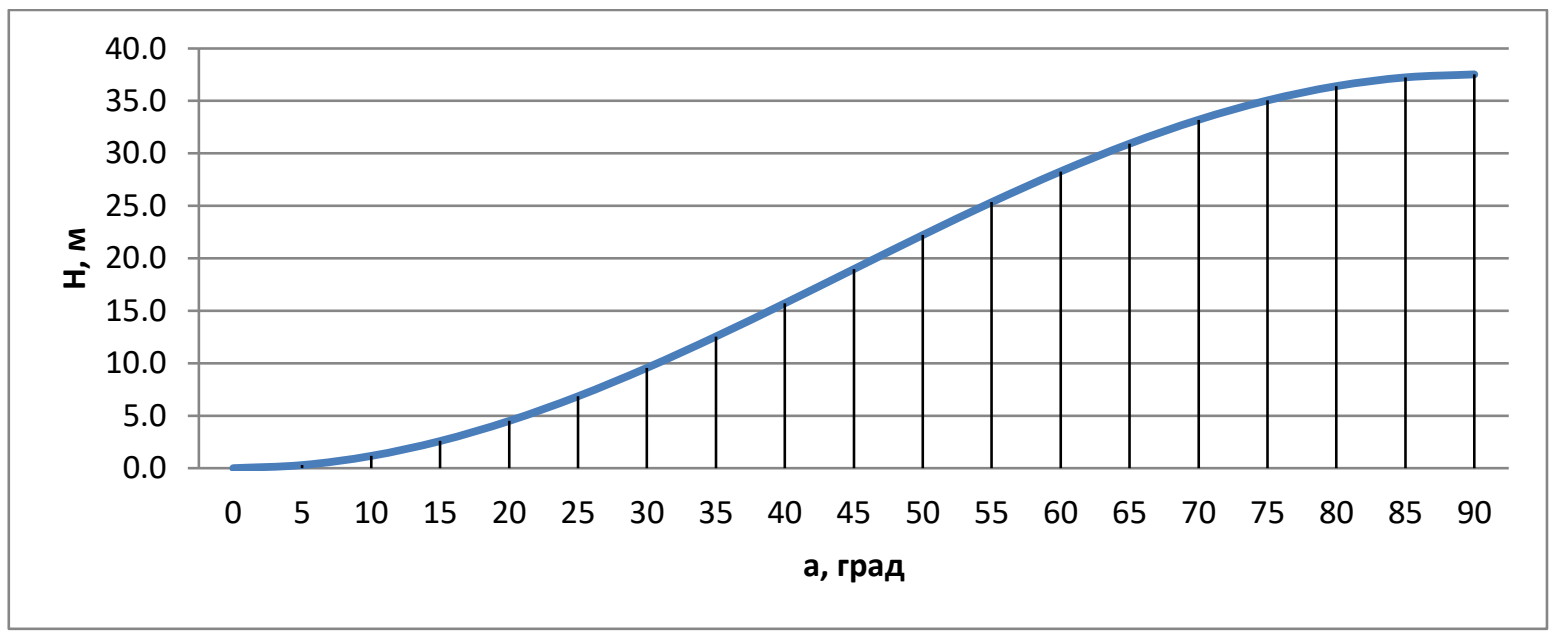

Рисунок 3 - Очікувана висота польоту елементу що тралить 


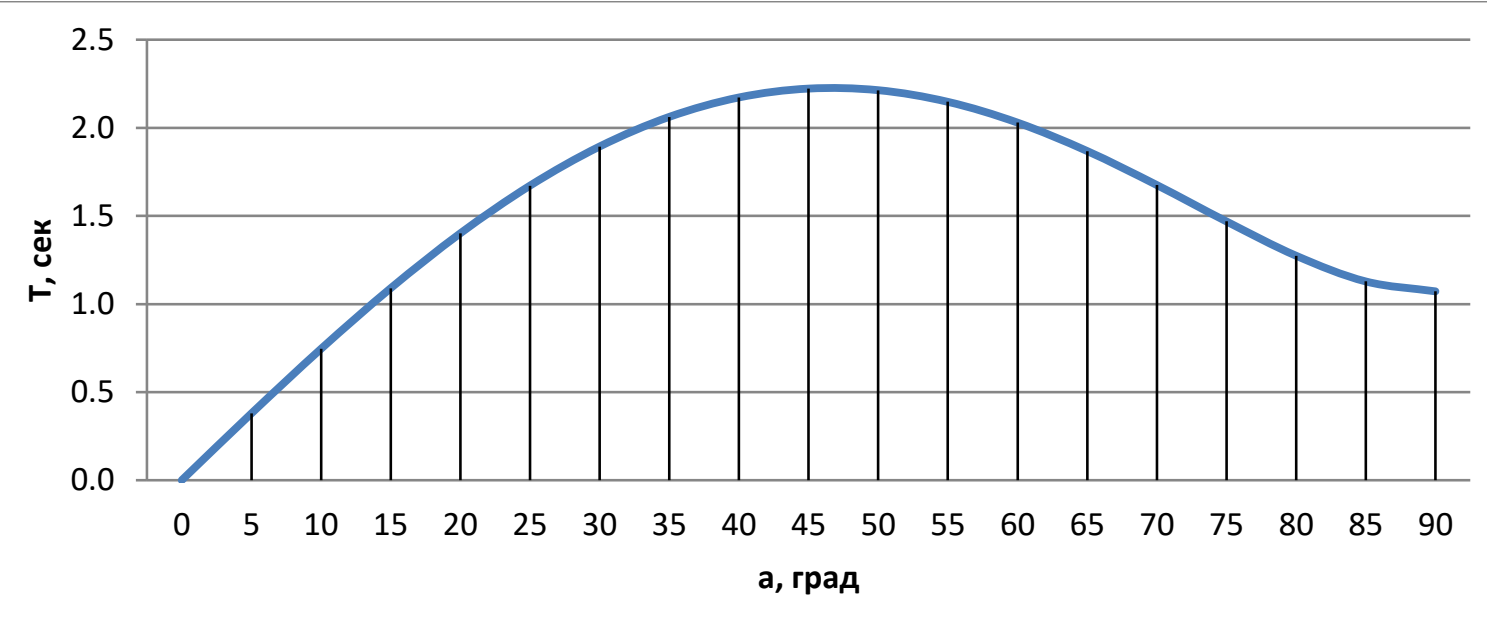

Рисунок 4 - Очікуваний час польоту елементу що тралить

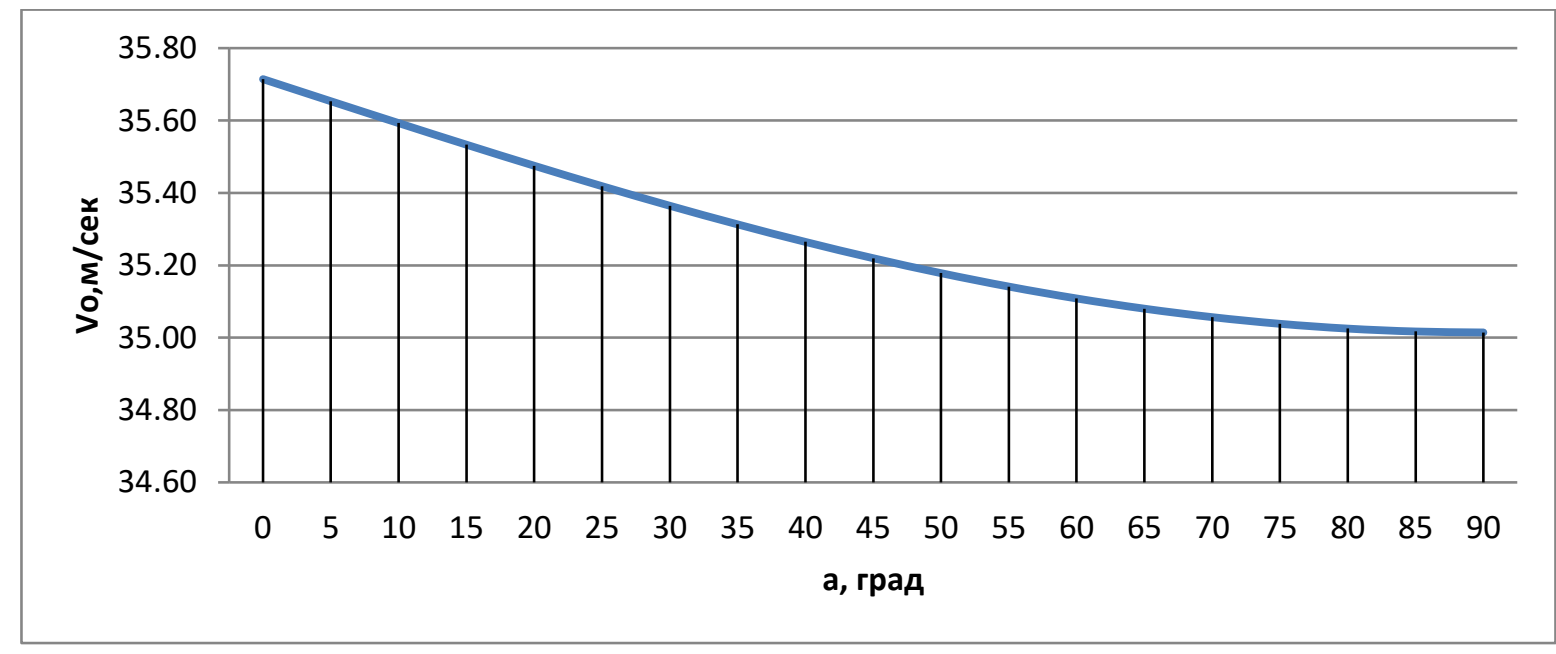

Рисунок 5 - Початкова швидкість польоту елементу що тралить

Розглянемо рух TE, кинутого під кутом $\theta_{0} 3$ початковою швидкістю $V_{0}$. Проецируємо початкову швидкість $\vec{V}_{0}$ та прискорення $\vec{a}$ на осі $\mathrm{X}$ та Y. Проекція початкової швидкості на вісь $\mathrm{X}$ дорівнює $V_{0 x}=V_{0} \cdot \cos \theta_{0}$. Проекція прискорення $a_{x}=0$, оскільки вектор $\vec{g}$ перпендикулярний осі X. Тому рух ТЕ вздовж осі $X$ буде рівномірним. Проекція швидкості $V_{x}$ та координата $x$ TE, що летить, визначається співвідношеннями

$$
\begin{gathered}
V_{x}=V_{0} \cdot \cos \theta_{0}, \\
x=x_{0}+V_{0} \cdot t \cdot \cos \theta_{0} .
\end{gathered}
$$

Проекція початкової швидкості на вісь $Y$ дорівнює $\quad V_{0 y}=V_{0} \cdot \sin \theta_{0} . \quad$ Проекція прискорення $a_{y}=-g$, оскільки вектор $\vec{g}$ спрямований у протилежному осі $Y$ напрямку. Тому вздовж осі $Y$ рух ТЕ рівнозмінний. В цьому випадку проекція швидкості $V_{y}$ та координата у TE, що летить, задається формулами

$$
\begin{gathered}
V_{y}=V_{0} \cdot \sin \theta_{0}-g \cdot t, \\
y=y_{0}+V_{0} \cdot t \cdot \sin \theta_{0}-\frac{g \cdot t^{2}}{2} .
\end{gathered}
$$

Коли ТЕ досягне точки $A$ (рис. 1), тобто максимальної висоти підйому, проекція його швидкості на вісь $Y$ буде рівною $V_{y}=0$. Тоді час підйому до максимальної висоти $t_{1}=V_{0}$. 
$\sin \theta_{0} / g$. Враховуючи це значення максимальна висота польоту ТЕ дорівнює

$$
H \frac{V_{0}^{2} \cdot \sin ^{2} \theta_{0}}{2 g} \max
$$

Якщо ТЕ кинутий з поверхні грунту $\left(y_{0}=\right.$ $0)$, тоді загальний час польоту буде рівний часу підйому

$$
T=\frac{2 V_{0} \cdot \sin \theta_{0}}{g}=0,903 \sqrt{H_{\max }}
$$

Відстань $L$, яку пролітає TE за певний час, визначається підстановкою часу $t_{0}$ польоту у залежність $x(t): L=x_{0}+V_{0} \cdot t_{0} \cdot \cos \theta_{0}$. При $x_{0}=0 \quad$ та $y_{0}=0$ дальність польоту TE дорівнює

$$
y=y_{0}+V_{0}\left(\frac{x-x_{0}}{V_{0} \cdot \cos \theta_{0}}\right) \cdot \sin \theta_{0}-\frac{g}{2}\left(\frac{x-x_{0}}{V_{0} \cdot \cos \theta_{0}}\right)^{2}=y_{0}+\left(x-x_{0}\right) \operatorname{tg} \theta_{0}-\frac{g\left(x-x_{0}\right)^{2}}{2 V_{0}{ }^{2} \cdot \cos ^{2} \theta_{0}}
$$

Якщо вибрати систему координат таким чином, що $x_{0}=0, y_{0}=0$, тоді формула спрощується

$$
y=x \cdot \operatorname{tg} \theta_{0}-\frac{g \cdot x^{2}}{2 V_{0}^{2} \cdot \cos ^{2} \theta_{0}} .
$$

Врахування характеристик TE та сили опору повітря швидкість польоту визначається виходячи із експоненціального закону затухання швидкості ТЕ при польоті тіла та здійснюється за виразом

$$
V_{x}=V_{0} \cdot \exp (-A \cdot x),
$$

де $A$ - балістичний коефіцієнт;

$x$ - змінна координата відстані польоту TE.

Коли політ ТЕ відбувається в умовах поступового збільшення ваги пристрою, що тралить, поточна швидкість польоту буде зменшуватись більш ніж при польоті тіла 3 постійною (не змінною) масою для таких саме умов. Це можна врахувати шляхом удосконалення виразу, який наведено в [8],

$$
L=\frac{V_{0}^{2} \cdot \sin 2 \theta_{0}}{g} .
$$

Максимальна дальність польоту тіла, яке кинуте з поверхні землі, згідно [7] досягається при куті кидання $\theta_{0}=45^{\circ}$, оскільки в цьому випадку $\sin 2 \theta_{0}=1$.

Визначимо, по якій траєкторії рухається ТЕ, тобто складемо рівняння, яке зв'язує між собою координати ТЕ по осях х та у. Для цього виразимо час із залежності $x(t)$

$$
t=\frac{x-x_{0}}{V_{0} \cdot \cos \theta_{0}}
$$

та підставимо його до формули (1) для визначення балістичного коефіцієнта $A$ шляхом врахування також параметру форми тросу $\Phi_{T P}$, який буде впливати на величину опору повітря. В роботі його пропонується визначати із врахуванням зміни маси пристрою, що тралить, за формулою

$$
A(x)=\frac{\rho_{\mathrm{\Pi}} \cdot \mathrm{C}_{\mathrm{X}} \cdot \Phi \cdot \Phi_{\mathrm{TP}}}{\sqrt[3]{8 \gamma_{0}^{2} \cdot\left(m+l \cdot m_{\mathrm{TP}}\right)}} \approx \frac{\rho_{\mathrm{\Pi}} \cdot \mathrm{c}_{\mathrm{x}} \cdot \Phi \cdot \Phi_{\mathrm{TP}}}{\sqrt[3]{8 \gamma_{0}^{2} \cdot\left(m+x \cdot m_{\mathrm{TP}}\right)}} .(7)
$$

де $\rho_{\text {п }}$ - щільність повітря вздовж траєкторії польоту (для повітря дорівнює 1,293 кг/м3);

$\mathrm{c}_{\mathrm{x}}$-коефіцієнт лобового опору;

$\gamma_{0}-$ щільність матеріалу TE;

$m$ - мaса TE;

Ф- параметр форми ТЕ;

$\Phi_{\mathrm{TP}}-$ параметр форми тросу;

$l$-змінна довжина тросу пристрою, що тралить, м (може бути прийнята $l \approx x$ ); $m_{\text {тр }}$ - питома маса тросу, кг/м.

Тоді вираз (5) буде мати вигляд

$$
V_{x}=V_{0} \cdot \exp (-A(x) \cdot x)
$$

\section{Висновки}

Таким чином, запропонована модель польоту $\mathrm{TE}$, яка, на відміну від існуючих, враховує приріст питомої маси та опір повітря тросу ЗТ під час польоту дозволить підвищити 
точність розрахунків під час обґрунтування балістичних параметрів засобів розмінування даного типу. Напрямами подальших досліджень $\epsilon$ висвітлення результатів

моделювання.

\title{
Список використаних джерел
}

1. Тематичний звіт ОБСЕ. Вплив мін, невибухлих боєприпасів та інших вибухонебезпечних предметів на цивільне населення в охоплених конфліктом областях на сході України [Електроний ресурс] // Спеціальна моніторингова місія ОБСЄ в Україні. 2021. - 31 с. URL: http://www.osce.org/ukraine-smm (дата звернення: 15.11.2021).

2. Про затвердження інструкції 3 правил поводження військовослужбовців на місцевості, на якій $€$ вибухонебезпечні предмети, та дотримання заходів мінної безпеки: Наказ Генерального штабу збройних сил України від 19.04.2018 року №161.

3. Конвенція про заборону застосування, накопичення запасів, виробництва i передачі протипіхотних мін та про їхнє знищення. - К.: Варта, 2004. - 25 с.

4. Про прийняття Протоколу про вибухонебезпечні предмети - наслідки війни: Закон України від 22.12.04 №2281-IV.

5. Про організацію робіт з виявлення, знешкодження та знищення вибухонебезпечних предметів на території України та взаємодію під час їх виконання: Спільний наказ Міністерства оборони України, Міністерства України з питань надзвичайних ситуацій та у справах захисту населення від наслідків Чорнобильської катастрофи, Міністерства оборони України, Міністерства транспорту та зв'язку України, адміністрації державної прикордонної служби України від 27.05.2008 року N 405/223/625/4553.

6. Фтемов, Ю. Системи озброєння і військова техніка. Науково-технічний журнал Харківського Національного Університету Повітряних Сил. - 2021. - №3. - С. 45-51.

7. Ментус І. Е. Ефективність інженерних боєприпасів: навч. посібник. Кам'янецьПодільський: ФВП ПДАТУ, 2008. 80 с.

8. Кошкин Н. И., Ширкевич М.Г. Справочник по элементарной физике. Москва: «Наука», 1976. - 256 с.

9. Шишанов, М., Коцюруба В. Балістична модель тралення вибухових пристроїв 3 натяжним датчиком цілі. Науковий журнал. Київ - 2016. - № 2. - С.95-98.

\section{Математическая модель полета элемента, тралящего натяжные датчики цели взрывоопасных предметов}

\footnotetext{
Владимир Кривцун * 1 А; Алексей Агеев 2 А; Олег Бондаренко ${ }^{3 \text { B }}$

* Corresponding author: ${ }^{1}$ к.тех.н., старший научный сотрудник, начальник кафедры, e-mail: vol.kryvtsun@gmail.com, ORCID: 0000-0002-3907-5320 2 адъюнкт научно-организационного отдела, e-mail: aheyev1979@ukr.net

${ }^{3}$ кандидат военных наук, доцент, доцент кафедры, e-mail: dinamo_kiev7@ukr.net, ORCID: 0000-0001-5360-0120

А Національна академія сухопутних військ імені гетьмана Петра Сагайдачного, г. Львів, Украина

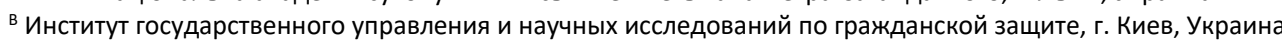

\begin{abstract}
Аннотация
На основе анализа существующих подходов по моделированию процессов разминирования, в частности использования средств для траления натяжных датчиков цели взрывоопасных предметов, предложена модель полета элемента, тралящего натяжные датчики цели, которая, в отличие от существующих, учитывает прирост удельной массы тралящего средства (комбинация тралящего элемента и троса) во время полета. Одним из наиболее сложных вопросов при моделировании является определение зависимости параметров полета тралящего элемента от динамики прироста массы троса
\end{abstract}


(шнура). Баллистическими параметрами исследуемого элемента являются: угол вылета, дальность, высота, время, скорость полета. Предложенные усовершенствования математической модели и последовательности проведения расчетов позволят повысить точность результатов моделирования процесса траления натяжных датчиков цели взрывоопасных предметов при обосновании требований к разминированию данного типа. Направлениями дальнейших исследований является математическое моделирование процесса полета тралящего элемента, входящих в состав средств для траления натяжных датчиков цели взрывоопасных предметов, и обоснование, на основе использования его результатов, рациональных баллистических параметров.

Ключевые слова: модель полета, взрывоопасный предмет, натяжной датчик цели, траление, тралящий элемент.

\title{
Mathematical model of flight of an element that drains tension sensors of entire explosion hazardous objects
}

\author{
Vladimir Krivtsun * 1 A; Oleksey Aheyev ${ }^{2}$; Oleh Bondarenko ${ }^{3 \text { B }}$ \\ * Corresponding author: ${ }^{1}$ Candidate of Technical Sciences, Senior Research, Head of Department, e-mail: vol.kryvtsun@gmail.com, ORCID: 0000-0002- \\ 3907-5320 \\ ${ }^{2}$ adjunct of scientific and organizational department, e-mail: i.marko94@gmail.com, ORCID:0000-0002-7208-3963 \\ ${ }^{3}$ Candidate of Military Sciences, Associate Professor, e-mail: aheyev1979@ukr.net \\ A Hetman Petro Sahaidachnyi National Army Academy, Lviv, Ukraine \\ ${ }^{B}$ Institute of public administration and research in civil protection, Kyiv, Ukraine
}

\begin{abstract}
Based on the analysis of existing approaches to modeling demining processes, in particular the use of means for trawling tension sensors of explosive objects, the flight model of the element trawling tension sensors of the target is proposed, which, in contrast to existing ones, takes into account trawling and rope) during the flight. One of the most difficult questions during modeling is to determine the dependence of the flight parameters of the trawling element on the dynamics of the growth of the mass of the cable (cord). The ballistic parameters of the trawling element under study are: departure angle, range, altitude, time, flight speed. The proposed improvements of the mathematical model and the sequence of calculations will increase the accuracy of the simulation results of the process of trawling the tension sensors of explosive objects while substantiating the requirements for demining equipment of this type. Areas of further research are mathematical modeling of the flight process of the trawling element, which are part of the means for trawling the tension sensors of the target of explosive objects, and substantiation, based on the use of its results, rational ballistic parameters.
\end{abstract}

Keywords: flight model, explosive object, the tension sensor of the purpose, sweeping, trawling element.

\section{References}

1. OSCE Thematic Report. Impact of mines, unexploded ordnance and other explosive devices on civilians in conflict-affected areas in eastern Ukraine [Electronic resource] // OSCE Special Monitoring Mission to Ukraine. 2021. - 31 p. Access mode: http://www.osce.org/ukraine-smm (access date: 15.11.2021).

2. On approval of the instruction on the rules of conduct of servicemen in areas where there are explosive devices and compliance with mine safety measures: Order of the General Staff of the Armed Forces of Ukraine dated 19.04.2018 №161.

3. Convention on the Prohibition of the Use, Stockpiling, Production and Transfer of AntiPersonnel Mines and on Their Destruction. Kyiv: Varta, 2004. 25 c. 
4. On Adoption of the Protocol on Explosive Substances - Consequences of War: Law of Ukraine of 22.12.04, №812281-IV.

5. On the organization of work on the detection, disposal and destruction of explosives in Ukraine and cooperation during their implementation: Joint Order of the Ministry of Defense of Ukraine, the Ministry of Emergencies and Protection of the Population from the Consequences of the Chornobyl Accident, the Ministry of Defense of Ukraine, the Ministry of Transport and Communications of Ukraine, the State Border Guard Service of Ukraine dated 27.05.2008 N405/223/625.
6. Ftemov, Yu. (2021). Weapons systems and military equipment. Scientific and Technical Journal of Kharkiv National University of the Air Force. №3. P. 45-51.

7. Mentus I. E Efficiency of engineering ammunition: a textbook. - KamyanetsPodilsky: FVP PDATU, 2008. 80 p.

8. Koshkin, N.I., Shirkevich, M.Г. Handbook of elementary physics. Moscow: "Science", 1976. $256 \mathrm{p}$.

9. Shishanov, M., Kotsyuruba V.I. (2016). Ballistic model of trawling of explosive devices with a tension target sensor. Scientific journal. Kyiv. № 2. P. 95-98. 